\title{
KURIKULM 2013 DALAM PROSES PEMBELAJARAN ONLINE PADA MASA PANDEMI COVID-19
}

\author{
E. Kurniyati *, Siswati** \\ *etykurniyati@umt.ac.id,**siswatiigra@gmail.com \\ *Dosen Program Pascasarjana Universitas Muhammadiyah Tangerang \\ **Mahasiswa Magister PAI Program Pascasarjana, Universitas Muhammadiyah Tangerang
}

\begin{abstract}
ABSTRAK
Penelitian ini bertujuan untuk mengidentifikasi untuk mendapatkan informasi yang berkaitan dengan dampak pandemi Covid-19 terhadap proses pembelajaran dan pelaksanaan kurikulum 13. Penelitian ini menggunakan metode Descriptive Content Analysis Study dan studi literatur yang merupakan sebuah analisis yang bertujuan untuk mendeskripsikan konten pokok berdasarkan kumpulan informasi yang diperoleh Informasi yang dimaksud bersumber dari berbagai artikel ilmiah yang berkaitan dengan pelaksanaan pembelajaran daring selama pandemi COVID-19. Artikel ilmiah yang dimaksud adalah artikel yang didapat dari jurnal Nasional serta jurnal Internasional bereputasi terindeks Scopus. Data dan informasi yang telah diperoleh, selanjutnya dikumpulkan, dianalisis, dan disimpulkan sehingga mendapatkan rekomendasi sebagai studi literatur. Hasil dari penelitian ini adalah terdapat beberapa rekomendasi sebagai studi literatur. Hasil dari penelitian ini adalah terdapat beberapa problematika yang dialami oleh peserta didik, guru, serta orang tua dalam kegiatan belajar mengajar online seperti penguasaan teknologi masih kurang, adanya penambahan biaya kuota internet, adanya pekerjaan tambahan untuk orang tua dalam mendampingi anak-anaknya belajar, komunikasi dan sosialisasi antar siswa yang menurun, guru dan orang tua menjadi kurang interaksinya dan Jam kerja yang menjadi tidak terbatas bagi guru karena harus berkomunikasi dan berkoordinasi dengan orang tua, guru dengan guru, dan guru dengan kepala sekolah setiap waktu. Pandemi COVID-19 mempengaruhi banyak hal termasuk kehidupan pendidikan, orang tua peserta didik, peserta didik dan proses pembelajaran, Sebagai seorang guru yang memiliki tanggung jawab untuk mendidik para siswa tidak dapat berhenti. Guru harus menemukan cara yang sesuai untuk mempromosikan proses pembelajaran secara akademis dan sosial-emosional. Guru harus dapat mengelola kelas online.
\end{abstract}

Kata Kunci :kurikulum 2013, Proses pembelajaran online dan Pandemi Covid-19

\section{A. PENDAHULUAN}

Dunia tengah dilanda wabah COVID-19 (Corona Virus Desease) yang dikabarkan berasal dari kota Wuhan, Cina sejak Desember 2019 (Lee, 2020). WHO menyatakan wabah ini sebagai pandemi global karena penularan virus ini sangatlah cepat dan sebagian besar negara di dunia turut terpapar virus ini. Data terkini menunjukkan jumlah pasien terkonfirmasi sebanyak 9.590.890 kasus positif pada 216 negara di seluruh dunia (Update: 24-06- 2020).

Indonesia merupakan salah satu negara yang turut terpapar virus ini sejak awal Maret hingga saat ini 27 Agustus 2020, konfirmasi 52.812 kasus positif yang tersebar di 34 provinsi dan 415 kabupaten/kota (Gugus Tugas 
Percepatan Penanganan COVID-19 Indonesia, 2020).

Menurut Sunitha et al (2020) COVID -19 yang sedang berlangsung adalah pandemi berkelanjutan yang dimulai pada Desember 2019 di Wuhan, Cina dan dinyatakan sebagai pandemi oleh WHO pada 11 Maret 2020. Hingga 16 Maret dilaporkan lebih dari 169.000 kasus dan lebih dari 140 negara terkena dampaknya.Wabah besar terjadi di Cina, Korea Selatan, Iran, dan Eropa 6.500 orang telah meninggal dan lebih dari 76.000 telah pulih dari penyakit ini. Tujuan dari studi ini adalah untuk fokus pada situasi COVID -19 sampai sekarang dampak sosialnya pada komunitas internasional. Tindakan keras diambil untuk mengurangi wabah: tindakan pencegahan pribadi yaitu menggunakan masker wajah, kebersihan tangan, dan karantina mandiri, langkahlangkah lingkungan yaitu seperti pembersihan permukaan dan tindakan masyarakat, nonaktif lembaga pendidikan dan perguruan tinggi untuk menjauhkan sosial, membatalkan pertemuan besar dan partisipasi dalam acara-acara publik. Di Wuhan, otoritas pusat menerapkan larangan transportasi pada 23 Januari. Karena wabah koronavirus, xenophobia, prasangka tinggi, rasisme dan kasus kecurigaan, ketakutan dan permusuhan telah dilaporkan oleh orang-orang Cina di banyak negara, seperti Amerika Utara, Eropa dan kawasan Asia Pasifik.

Dampak besar lain dari wabah penyakit adalah pembatalan acara besar di industri film, olah raga, dan industri lainnya. Banyak konser, festival musik, peragaan busana dan konferensi dibatalkan atau ditunda. Pemerintah telah menutup sementara semua lembaga pendidikan, di seluruh negara untuk membatasi penyebaran virus corona dan pada 14 Maret, sekitar 420 juta anak tidak bersekolah. Beberapa contoh kekurangan pasokan barang penting, pembelian secara menimbun barang, operasi logistik, peningkatan penggunaan peralatan kebersihan pribadi terjadi karena wabah koronavirus. Ada hampir91.000 kasus aktif di 73 negara dan banyak pembatasan kegiatan sosial dan ekonomi yang berdampak negatif pada pengeluaran konsumen dan rantai pasokan di seluruh dunia. Karenanya dampak COVID -19 akan signifikan.

COVID -19 yang sedang berlangsung (Penyakit Coronavirus 2019) adalah pandemi berkelanjutan yang merupakan sindrom pernapasan yang disebabkan oleh coronavirus 2 (Who.int, 2020). Wabah dimulai pada Desember, 2019 di Wuhan, Cina dan dinyatakan sebagai pandemi oleh WHO (Organisasi Kesehatan Dunia) pada tanggal 11 Maret, 2020 (Direktur WHO, 2020). Hingga tanggal 20 Maret lebih dari 245.972 kasus dilaporkan dan lebih dari 160 negara terpengaruh (Worldometer, 2020). Wabah besar terjadi di Cina, Korea Selatan, Iran, dan Eropa. 10.000 orang telah meninggal dan lebih dari 88.400 telah pulih dari penyakit (Worldometer, 2020). Virus ini menyebar di antara orang-orang dengan cara yang sama influenza menggunakan tetes respirasional yang disebabkan karena bersin dan batuk (WHO, 2020). Biasanya dibutuhkan 2 hingga 5 hari untuk menunjukkan gejala setelah terpapar virus tetapi juga dapat memakanwaktu hingga 14 hari (WHO,2020). Gejala umum adalah demam, masalah pernapasan dan batuk (WHO, 2020). Kasus - kasus yang lebih rumit dapat berupa gejala - gejala seperti sindrom tekanan pernapasan parah dan pneumonia. Saat ini, tidak ada antibiotik atau vaksin khusus untuk mengobatinya, tetapi para peneliti sedang mengusahakannya.

Upaya difokuskan pada menyembuhkan gejala dan pengobatan terkait diberikan kepada pasien. Tindakan pencegahan berikut disarankan: cuci tangan sesering mungkin, jaga jarak fisik dari orang, tutup mulut selama batuk, isolasi sendiri untuk orang yang diduga atau mengunjungi negara yang terinfeksi atau melakukan kontak dengan orang yang terinfeksi (Rothan \& Bycldy, 2020). 


\section{Dampak pada Pendidikan}

Pemerintah telah menutup sementara semua sekolah, di seluruh negara untuk membatasi penyebaran virus corona dan pada 14 Maret, sekitar 420 juta anak tidak bersekolah. Lebih dari tiga belas negara telah menutup sementara semua sekolah mereka yang telah mempengaruhi siswa dari hampir semua kelas. Selain itu, sembilan negara termasuk India telah menutup sekolah mereka di tingkat lokal untuk mencegah COVID -19, yang telah mempengaruhi lebih dari 85 juta anak -anak (Berita PBB, 2020). Meskipun sekolah-sekolah ditutup sementara, bahkan saat itu dampak ekonomi yang besar dan biaya sosial. UNESCO telah merekomendasikan program pembelajaran jarak jauh dan platform pendidikan online lainnya sehingga guru dan sekolah dapat menjangkau siswa dan gangguan pendidikan dapat dikurangi selama penutupan sekolah yang disebabkan karena COVID -19 (UNESCO, 2020).

Kebijakan pemerintah Indonesia dalam menyikapi wabah ini adalah dengan memberlakukan prinsip social distancing pada seluruh lapisan masyarakat, bahkan di beberapa kota besar di Indonesia diberlakukan pula PSBB (Pembatasan Sosial Berskala Besar) guna memutus rantai penyebaran virus ini. Kebijakan tersebut memberikan dampak pada pendidikan di Indonesia khususnya pada proses pembelajaran bagi siswa sekolah. Penerapan social distancing pada jenjang sekolah dasar dan menengah sampai perguruan tinggi terus dilaksanakan hingga kondisi dinyatakan kondusif. Selama pandemi berlangsung, sekolah memangdiliburkan tetapi proses pembelajaran harus tetap berlangsung. Sejauh ini, belum pernah pembelajaran dengan sistem daring dilakukan secara serentak. (Sun et al.,2020). Selama pandemi berlangsung, kini pembelajaran daring telah dilakukan di hampir seluruh dunia (Goldschmidt, 2020). Sehingga, pada pembelajaran daring ini, semua elemen pendidikan dituntut untuk tetap mampu memfasilitasi pembelajaran agar tetap aktif meskipun tanpa tatap muka secara langsung.

Guru selaku elemen utama dalam pendidikan formal dipacu untuk melakukan adaptasi dengan pelaksanaan pembelajaran yang semula menggunakan metode tatap muka konvensional dan beralih kepembelajaran daring Menrut Daryanto (2014), Fadlillah (2014), Keyes (2010), Kunandar (2013) bahwa tema pembaharuan dan perbaikan pada Kurikulum 2013 yaitu ingin menciptakan manusia indonesia yang mampu berpikir kreatif, produktif, inovatif, proaktif,dan afektif, melalui pengembangan sikap(tahu mengapa), keterampilan (tahu bagaimana), dan pengetahuan (tahu tentangapa) secara integratif. Pengintegrasian inimerupakan salah satu upaya untuk memperbaiki peringkat Indonesia berdasarkan studi TIMSS (Trends in International Mathematics and Science Study) dan Program for International Student Assessment (PISA), Dimana pada 2011 peserta didik hanya mampu sampai level 3 dari 6 (enam) level kemampuan kognitif yang berkaitan dengan kemampuan berpikir tingkat tinggi (berpikir kritis, berpikir kreatif, analitis, sistematis dan logis untuk menemukan alternative pemecahan masalah melalui eksplorasi data secara empiris dalam rangka menumbuhkan sikap ilmiah). Begitu juga kemampuan siswa Indonesia dalam memahami informasi yang kompleks, pemecahan masalah, pemakaian alat, prosedur, pemecahan masalah dan melakukan investigasi yang masih berada rendah dan perlu ditingkatkan. Penelitian ini akan membahas pengaruh dari pandemi Covid-19 terhadap proses pembelajaran di sekolah, pengaruh terhadap peserta didik, pengaruh terhadap orang tua dan pengaruh terhadap proses pembelajaran pelaksanaan kurikulum 13. Penelitian tentang model pembelajaran lain juga dilakukan oleh Setyani et al2020), Murtono et al (2019), Ismaya et al (2019), Utaminingsih et al (2020 


\section{B. METODE PENELITIAN}

Penelitian ini menggunakan metode Descriptive Content Analysis Study dan studi litertur yang merupakan sebuah analisis yang bertujuan untuk mendeskripsikan konten pokok berdasarkan kumpulan informasi yang diperoleh (Herliandry et al., 2020). Informasi yang dimaksud bersumber dari berbagai artikel ilmiah yang berkaitan dengan pelaksanaan pembelajaran daring selama pandemi COVID-19. Artikel artikel ilmiah yang dimaksud adalah artikel yang didapat dari jurnal Nasional serta jurnal Internasional bereputasi terindeks Scopus. Data dan informasi yang telah diperoleh, selanjutnya dikumpulkan, dianalisis, dan disimpulkan sehingga mendapatkan rekomendasi sebagai studi litaratur.

\section{PEMBAHASAN}

\section{Analisis Dampak Pandemi Covid-19 Terhadap Orang Tua Peserta Didik \\ Menurut arwen et al (2020),} Sunitha (2020) dan Duocet (2020), dampak belajar di rumah juga dirasakan oleh orang tua yang juga memiliki beban lebih karena harus menjadi guru di rumah, mengajar membuat tugas, dan selalu memantau. Dapat dibayangkan jika anak lebih dari satu dan masih membutuhkan bantuan dalam melakukan tugas.Belum lagi harus menyiapkan makanan dan pekerjaan rumah tangga lainnya. Sukacita dan kesedihan selama proses belajar di rumah bervariasi. Beberapa orang tua lebih suka anak-anak belajar di sekolah. Selain biaya internet yang membengkak, salah satu keluhan orang tua adalah peningkatnya pengeluaran untuk konsumsi yang lebih besar dari pada tunjangan anak setiap hari. Namun, nilai positifnya adalah bahwa ada lebih banyak waktu untuk berkumpul dengan keluarga dan untuk mendekatkan hubungan emosional antara orang tua dan anak-anak. Dan yang lebih penting adalah keluarga lebih terlindungi dari paparan virus korona.

Menurut Purwanto et al (2020) dan Putri et al (2020) dengan tinggal di rumah untuk memutus rantai penyebaran virus memang merupakan solusi yang tepat. Namun hal ini tidak terlepas dari masalah yang akan terjadi di masa depan, seperti tidak mampu untuk melakukan berbagai kegiatan normal pada umumnya tetapi di tempat kerja. Goldschmidt (2020), Drel (2020), Bacow (2020) jika masyarakat tidak bekerja, maka mereka tidak akan mendapatkan penghasilan dan jika mereka tidak mendapatkan penghasilan, maka mereka tidak dapat memenuhi kebutuhan sehari -hari selama di rumah. Jika dibiarkan lama-lama akan sangat mengganggu keseimbangan ekonomi masyarakat.

Untuk mengatasi hal ini, pemerintah melalui kebijakan Work From Home (WFH) diharapkan untuk membuat masyarakat lebih mudah untuk terus bekerja bahkan di tengah-tengah pandemi virus yang mengharuskan mereka tetap ada. Melalui kebijakan ini masyarakat menganggap bahwa bekerja di rumah akan sangat memudahkan mereka, tetapi ini tidak dapat dipisahkan dari pekerjaan sistem yang semakin sulit.

\section{Dampak Pandemi Covid-19 Terhadap Guru}

Menurut Purwanto et al (2020) dan Putri et al (2020) WFH memiliki kelebihan dan kekurangan guru, WFH dapat dilakukan secara efektif jika guru dan sekolah melaluinya dengan bertanggung jawab. Kedua belah pihak harus lebih memahami tentang kondisi yang terjadi, sambil memberikan kinerja terbaik yang mungkin, meskipun mereka bekerja ditempat yang berbeda.Jangan lupa memaksimalkan komunikasi untuk menghindari hal-hal yang tidak diinginkan. Montacute, R. (2020), Lederman, (2020) manfaatkan teknologi dengan baik, buatlah daftar hal-hal yang ingin Anda lakukan lebih terencana, juga sertakan hasil yang diharapkan sehingga guru tidak akan salah sehari kerja dari rumah dengan nonproduktivitas.

Apabila guru masih harus


bekerja, jangan lupa untuk memperhatikan kebersihan setiap outlet dan kesehatan. rajin mencuci tangan dengan sabun dan air mengalir. Sunitha (2020), Duocet (2020) perlu memberikan pembersih tangan di setiap outlet untuk digunakan oleh guru lain yang masih akan datang. Ketika bekerja di rumah, tentu saja laptop komputer menjadi alat kerja utama. Selalu pastikan laptop bersih dari kuman, baterai terisi penuh, dan semua aplikasi di dalamnya dapat berjalan dengan baik agar tidak lambat dalam menyelesaikan pekerjaan.Saat bekerja, internet menjadi salah satu dukungan yang harus Anda persiapkan. Dengan koneksi internet yang stabil, Anda dapat terhubung dengan mudah dengan orang lain.

Netolicky (2020) terutama ketika Work From Home, ruang kerja pengajar yang lengkap juga sangat penting untuk dipersiapkan. Dukungan akses internet yang memadai dan biaya rendah juga sangat membantu dalam persoalan tersebut. Sumber daya manusia dalam hal ini juga harus mulai ditingkatkan, karena dengan begitu semua pekerjaan yang semestinya mudah dilakukan dengan kemajuan teknologi yang cepat dan tepat dapat dilakukan dengan baik tanpa hambatan. Masyarakat juga harus mulai memikirkan pekerjaan sampingan yang dapat diterapkan dalam berurusan dengan kondisi tertentu yang tidak mungkin seperti sekarang ini.

\section{Dampak Pandemi Covid-19 Terhadap Proses Pembelajaran}

Implementasi pembelajaran

secara daring ini paling banyak dilaksanakan dengan menggunakan aplikasi WhatsApp (Dewi, 2020), (Gunawan et al., 2020), (Purwanto et al., 2020) dengan pertimbangan rata-rata guru dan siswa atau orang tua siswa memiliki aplikasi ini pada gadget masingmasing. Aplikasi ini memiliki fitur Whats App Group sehingga guru dan siswa dapat berdiskusi serta saling berbagi dokumen. Guru memanfaatkan fitur ini untuk membagi dokumen materi pembelajaran dan tugas bagi siswa, kemudian siswa akan mengirimkan tugas yang telah mereka selesaikan melalui grup ini pula.

Hal yang perlu diperhatikan adalah pemberian tugas disertai pemantauan dan pendampingan oleh guru. Langkah yang dilakukan adalah guru meminta bantuan orang tua maupun kakak siswa sebagai nara hubung dengan pemberitahuan lebih dulu melalui WhatsApp Group. Selain itu, perlu disertakan pula koordinasi dan interaksi antara guru dan orang tua siswa berupa video call maupun foto dokumentasi kegiatan belajar siswa di rumah sebagai bentuk laporan bahwa siswa benar-benar melaksanakan pembelajaran di rumah (Wicaksono \& Rachmadyanti, 2017).

Menurut Putri et al (2020) dan Purwanto et al (2020) mengungkapkan beberapa tantangan dan kendala yang dialami oleh siswa, guru, dan orang tua dalam pembelajaran online. Tantangan yang terkait dengan siswa adalah: komunikasi dan sosialisasi yang terbatas di antara siswa, tantangan yang lebih tinggi bagi siswa dengan kebutuhan pendidikan khusus, dan waktu penyaringan yang lebih lama. Orang tua melihat masalah itu lebih terkait dengan kurangnya disiplin belajar di rumah, lebih banyak waktu yang dihabiskan untuk membantu belajar anak-anak mereka di rumah-terutama untuk anak -anak di bawah kelas 4 di Sekolah Dasar, kurangnya keterampilan teknologi, dan tagihan internet yang lebih tinggi.

Menurut Putri et al (2020) Guru mengidentifikasi lebih banyak tantangan dan kendala, termasuk beberapa pembatasan dalam pilihan metode pengajaran yang biasanya berlaku di kelas tatap muka reguler, cakupan materi kurikulum yang lebih sedikit, kurangnya keterampilan teknologi yang menghambat potensi pembelajaran online, kurangnya kemampuan -berbagai sumber dalam bahasa Indonesia yang menghasilkan lebih banyak waktu yang dibutuhkan untuk mengembangkan konten-e, waktu layar 
yang lebih lama sebagai hasil dari pembuatan konten-e dan memberikan umpan balik pada pekerjaan siswa, komunikasi yang lebih intens dan memakan waktu dengan orang tua, tantangan untuk koordinasi yang lebih baik dengan guru, kepala sekolah, dan tagihan internet yang lebih tinggI.

$$
\text { Menurut Zahra et al (2020) }
$$

kelas online dalam waktu COVID menghabiskan banyak biaya. Ada beberapa hal yang harus dipertimbangkan untuk pengajaran yang lebih baik dalam proses pembelajaran kelas online, yaitu: (1) Video yang direkam dapat membantu pembelajaran jika koneksi internet tertunda, (2) Yakinkan bingkai video yang direkam wajah guru, sehingga siswa memahami lebih baik saat kelas berjalan, (3) Video kurang dari 10 menit sudah cukup untuk menutupi materi. Jika materi semakin lama, pertimbangkan untuk membuat serangkaian video pembelajaran, (4) Pertimbangkan memiliki teks yang dapat dibaca pada layar kecil, (5) Optimalkan video yang tersedia daripada membuat yang baru, (6) Letakkan video di akses terbuka, (7) menginstruksikan agar para siswa tidak hanya menonton tetap ingin juga, mereka mencoba mengikuti instruksi yang diberikan, (8) Buat satu set pelajaran interaktif yang baik untuk mempromosikan pemikiran kritis siswa, (9) Atur kuis untuk mendapatkan jawaban dari sumber yang disediakan, (10) Gunakan sistem otomatis untuk menghadiri kelas dan menilai tes, (11) berikan pilihan untuk rapat konferensi. Hal ini memungkinkan siswa untuk memiliki tanggung jawab dalam belajar dan untuk mengelola koneksi internet mereka (setiap siswa berbeda), (12) Biarkan mereka melakukan diskusi kelompok kecil untuk menjaga aspek social, (13) Tunjukkan kebenarannya pada guru. Ini membantu pembelajaran emosional siswa dan akan mendorong mereka untuk mendukung proses pembelajaran bersama. Mempertimbangkan untuk mengebor kegiatan untuk menemukan proses belajar yang cocok di kelas, dan (15) meminta orang tua untuk mendukung proses pembelajaran online.

\section{KESIMPULAN}

Hasil dari penelitian ini adalah terdapat beberapa problematika yang dialami oleh peserta didik, guru,serta orang tua dalam kegiatan belajar mengajar online seperti penguasaan teknologi masih kurang, adanya penambahan biaya kuota internet, adanya pekerjan tambahan untuk orang tua dalam mendampingi anak -anaknya belajar, komunikasi dan sosialisasi antar siswa yang menurun, guru dan orang tua menjadi berkurang interaksinya dan Jam kerja yang menjadi tidak terbatas bagi guru karena harus berkomunikasi dan berkoordinasi dengan orang tua, guru lain, dan kepala sekolah setiap waktu. Pandemi COVID-19 mempengaruhi banyak hal termasuk kehidupan pendidikan, orang tua peserta didik, peserta didik dan proses pembelajaran, Sebagai seorang guru yang memiliki tanggung jawab untuk mendidik para siswa tidak dapat berhenti. Guru harus menemukan cara yang sesuai untuk mempromosikan proses pembelajaran secara akademis dan sosial-emosional. Guru harus dapat mengelola kelas di kelas dan kelas online.

Pandemi COVID-19 mempengaruhi banyak hal termasuk kehidupan pendidikan, orang tua peserta didik, peserta didik dan proses pembelajaran, Sebagai seorang guru yang memiliki tanggung jawab untuk mendidik para siswa tidak dapat berhenti. Guru harus menemukan cara yang sesuai untuk mempromosikan proses pembelajaran secara akademis dan sosialemosional.

Guru harus dapat mengelola kelas di kelas dan kelas online. Berdasarkan hasil review dan pembahasan, dapat disimpulkan bahwa sistem pembelajaran daring dengan memanfaatkan platform digital pada jenjang sekolah dasar dan menengah cenderung mengubah wajah pendidikan ke 
arah yang lebih baik, lebih efektif, dan lebih menyenangkan. Gurupun menjadi semakin inovatif dalam mengemas bahan ajar dan semakin kreatif mengembangkan metode pembelajaran untuk menarik antusisme siswa. Meski demikian, perlu dilakukan penyesuaian kembali dengan beragam kemampuan masing-masing guru, siswa, dan orang tua siswa dalam memberikan fasilitas pembelajaran daring ini, sehingga kendala yang dialami dapat diminimalisir.

\section{DAFTAR PUSTAKA}

Agus Purwanto, Masduki Asbari, Mochammad Fahlevi, Abdul Mufid, Eva Agistiawati, Yoyok Cahyono, Popong Suryani. (2020). Impact of Work From Home (WFH) on Indonesian Teachers Performance During the Covid-19 Pandemic : An Exploratory Study. International journal of Advanced Science and Technology, 29(05), 6235 -6244.Retrieved from http://sersc.org/journals/index.php/IJ AST/article/view/156272).

Aini Indriasih, Sumaji, Badjuri, dan Santoso (2020) Pengembangan EComic Sebagai Media Pembelajaran Untuk Meningkatkan Kecakapan Anak.Refleksi Edukatika : Jurnal Ilmiah Kependidikan, Volume 10, Nomor 2, Juni 2020, hlm. 154-162.

Budi Setyani, Murtono, Slamet Utomo (2020). Pengaruh Model Pembelajaran PBL terhadap Hasil Belajar Pengaruh Model Pembelajaran PBL Terhadap Hasil Belajar Matematika Pada SiswaSDN Sari 1 Kelas V Kecamatan Gajah Kabupaten Demak,Jurnal Pengabdian Multidisiplin,Volume 2 Nomor 1, April 2020, 28-43

Desri Arwen. (2020). Student Learning Motivation Influences The Development Of The Corona Virus Pandemic (COVID 19). International Journal of $\begin{array}{lrr}\text { Advanced } & \text { Science } & \text { and } \\ \text { Technology, } & 29(9 s), & 4911- \\ \text { 4925.Retrieved } & & \text { from }\end{array}$ http://sersc.org/journals/index.php/IJ AST/article/view/17339.

Dr. Soundarya N. (2020). A study on COVID -19's effect on Teaching Learning Process in Engineering Educationin the Post Pandemic Indian Education Market. International Journal of Advanced Science and Technology, 29(08), $\quad 2395$-2414.Retrieved from

http://sersc.org/journals/index.php/IJ AST/article/view/234096).

Daryanto.(2014). Pendekatan pembelajaran saintifik Kurikulum2013. Yogyakarta:Gava Media.

Fadlillah, M. (2014).Implementasi Kurikulum2013 dalam pembelajaran SD/MI SMP/MTS, dan SMA/MA. Yogyakarta:Ar-Ruzz Media.

Hosnan, M. (2014).Pendekatan saintifik dankontekstua ldalam pembelajaran abad21:kunci sukses implementasi Kurikulum2013. Bogor: Ghalia Indonesia.

Keyes, G. (2010). Teaching the scientific method in the social sciences. The Journal of Effective Teaching, 10(2), 18-28. Retrieved from http://www.uncw.edu/jet/articles/Vol 10_2/Volume1002.

Kunandar. (2013).

Penilaian autentik:penilaian hasil belajar peserta didik berdasarkan Kurikulum 2013. Jakarta:Rajawali Pers.

Ratna Setyowati Putri, Agus Purwanto, Rudy Pramono, Masduki Asbari, Laksmi Mayesti Wijayanti, Choi Chi Hyun. (2020). Impact of the COVID-19 Pandemic on Online Home Learning: An Explorative Study of Primary Schools in Indonesia. International Journal of Advanced Science and Technology, 29(05), 4809 4818. Retrieved from http://sersc.org/journals/index.php/IJ AST/article/view/13867. 
Dewi, W. A. F. (2020). Dampak Covid-19 terhadap implementasi pembelajaran daring di Sekolah Dasar. Edukatif: Jurnal Ilmu Pendidikan, 2(1), 55-61.13) acow, L.(2020). $\quad$ COVID-19 -Moving classes online, other updates.[Community

Message].Harvard

University.https://www.harvard.edu/ covid-19-moving-classes-onlineother-updates.

Bai, Y. , Yao, L., Wei, T., Tian, F. , Jin, D.-Y., Chen, L. ,\& Wang, M. (2020). Presumed asymptomatic carrier transmission of COVID19. Journal of the American Medical Association, 323 (14), 1406-1407.

https://doi.org/10.1001/jama.2020.25 65.

Drell, P. (2020, March 6). COVID19 update from Provost Persis Drell.[Community Update].Stanford University. https://news.stanford.edu/2020/03/06

/covid.update-provost-persis-drell/

Gunawan, G., Suranti, N. M. Y., \& Fathoroni, F. (2020). Variations of Models and LearningPlatforms for Prospective Teachers During the COVI-19 Pandemic Period.

Indonesian Journal of Teacher Education, 1(2), 61-70.17)Goldschmidt, K. (2020). The COVID-19 Pandemic: Technology Use to Support the Wellbeing of Children. Journal of Pediatric Nursing.

Lai, C.-C. , Shih, T.-P. , Ko, W.-C. , Tang, H.-J. , \& Hsueh, P.-R. (2020). Severe acute respiratory syndrome coronavirus 2 (SARSCoV-2) and coronavirus disease2019 (COVID-19): The epidemic and the challenges. International Journal of Antimicrobial Agents , 55 (3), $1-9$. https://doi.org/10.1016/j.ijantimicag. 2020.105924. 